\title{
Sosialisasi Peran Bank Sampah dalam Meningkatkan Kesehatan Lingkungan dan Kesejahteraan Masyarakat
}

\author{
Wiwik Tiswiyanti $^{1}$, Dewi Fitriyani ${ }^{2 *}$, Fitrini Mansur ${ }^{3}$, Suswita Roza ${ }^{4}$, Widya Sari Wendry ${ }^{5}$ \\ ${ }^{1,2,3,4,5)}$ Program Studi Akuntansi, Fakultas Ekonomi dan Bisnis, Universitas Jambi
}

\begin{tabular}{|l|l|l|l|}
\hline Diterima: 08-11-2021 & Direvisi: 14-12-2021 & Disetujui: 22-12-2021 & Dipublikasi: 31-12-2021 \\
\hline
\end{tabular}

\begin{abstract}
Waste can be used to increase people's income, for example, through the establishment of Waste Bank (Bank Sampah). Its establishment can have a positive impact on society and the environment. The goal of this community service is to solve the problems faced by partners through the role of waste bank in improving environmental health and community welfare. The activity was helf on September 7, 2020 at the Simpang Sungai Duren Village office, attended by 20 participants consisting of leaders and BumDes officers. It was carried out in the form of socialization. Participants showed their enthusiasm by asking and discussing about how to set up a waste bank and other things related to it and its benefits for the environment and community health and welfare.
\end{abstract}

Keywords: waste bank, environmental health, community welfare

\begin{abstract}
Abstrak
Sampah dapat dimanfaatkan untuk menambah penghasilan masyarakat seperti melalui pendirian Bank Sampah. Pendirian bank sampah dapat memiliki dampak yang positif bagi masyarakat dan lingkungan. Tujuan kegiatan pengabdian ini adalah untuk menyelesaikan permasalahan yang dihadapi oleh mitra melalui peran bank sampah dalam meningkatkan kesehatan lingkungan dan kesejahteraan masyarakat. Pengabdian dilaksanakan pada tanggal 7 September 2020 di Kantor Desa Simpang Sungai Duren dan diikuti oleh 20 orang peserta yang terdiri dari tua tengganai dan pengelola BumDes. Kegiatan pengabdian dilaksanakan dengan metode ceramah berupa sosialisasi. Antusiasme peserta kegiatan menunjukkan keingintahuan peserta bagaimana cara mendirikan bank sampah dan hal lain terkait bank sampah serta manfaatnya bagi warga lingkungan dan kesehatan masyarakat sekitar.
\end{abstract}

Kata kunci: bank sampah, kesehatan lingkungan, kesejahteraan masyarakat

\section{Pendahuluan}

Kabupaten Muaro Jambi memiliki 11 kecamatan, 150 desa, dan 5 kelurahan. Desa Simpang Sungai Deran merupakan salah satu bagian dari Kecamatan Jambi Luar Kota (Jaluko) dari keseluruhan 20 desa dan 43 dusun. Kecamatan ini juga memiliki luas 280,12 $\mathrm{km}^{2}$ atau sebesar 5,32\% dari keseluruhan luas wilayah Kabupaten Muaro Jambi. Secara geografis, kecamatan ini berbatasan dengan Kecamatan Sekernan di sebelah utara, Desa Mestong di sebelah selatan, Kumpeh Ulu di sebelah timur, dan Kecamatan Pemayung di sebelah barat. Selain itu, 56\% desanya berada di pinggiran Sungai Batanghari. Desa Simpang Sungai Duren terletak di ketinggian 18 meter dari permukaan laut dengan mayoritas penduduk memiliki mata pencaharian di sektor pertanian dan perkebunan sebagai petani sawit dan karet.

Seiring dengan pertumbuhan penduduk yang semakin pesat, maka masalah sampah menjadi permasalahan bagi pemerintah termasuk kepala desa di Desa Simpang Sungai Duren.

\footnotetext{
* Penulis korespondensi

Email: dewi_fitriyani@unja.ac.id
} 
Sampah merupakan sisa-sisa limbah atau material yang tidak digunakan setelah kita melakukan aktivitas/proses, misalnya limbah rumah tangga setelah memasak, dll. Sampah yang dihasilkan setiap rumah tangga di Desa Simpang Sungai Duren apabila dikelola dengan baik dapat berdampak positif bagi masyarakat. Usaha pemerintah desa terkait sampah yang dihasilkan masyarakat setempat adalah menjadikan sampah tersebut sebagai salah satu peluang usaha. Pada akhirnya, hal ini dapat meningkatkan pendapatan asli desa (PAD) melalui Bumdes dengan cara mengelola peluang sampah rumah tangga dari komplekkomplek perumahan di Desa Simpang Sungai Duren. Salah satu upaya untuk membantu kelancaran usaha ini yaitu armada angkutan sampah berupa mobil pick up yang merupakan bantuan dari pemerintah sejak 2016. Menurut informasi aparat setempat, permasalahan sampah saat ini belum selesai dan usaha mengatasi masalah sampah tidak berjalan sebagaimana mestinya.

Di Desa Simpang Sungai Duren, pembuangan sampah oleh rumah tangga dilakukan secara konvensional, seperti dibakar atau dibuang pada tempat pembuangan sampah. Aparat desa telah mencoba menyelesaikan masalah sampah melalui Bumdes tetapi tidak berjalan sebagaimana yang diharapkan. Oleh karena itu, tim pengabdian menawarkan solusi lain, yaitu mendirikan Bank Sampah. Berdasarkan wawancara dengan aparat desa setempat, diketahui bahwa belum pernah berdiri Bank Sampah di Desa Simpang Sungai Duren. Pemahaman masyarakat mengenai bank sampah dan peran bank sampah bagi kehidupan masyarakat dan lingkungan masih sangat rendah. Sehingga, tim melaksanakan pengabdian kepada masyarakat untuk mensosialisasikan peran bank sampah dalam meningkatkan kesehatan lingkungan dan kesejahteraan masyarakat.

Tujuan dan manfaat kegiatan pengabdian ini yaitu untuk memberikan solusi dengan memberikan arahan bagi masyarakat setempat dan desa, khususnya memanfaatkan sampah melalui pendirian Bank Sampah, manajemen Bank Sampah, dan meningkatkan kesehatan lingkungan dan kesejahteraan masyarakat.

\section{Metode Pengabdian}

Kegiatan pengabdian memiliki beberapa tahapan dan metode dalam pelaksanaannya, yaitu sebagai berikut :

1. Metode ceramah, yaitu digunakan untuk memaparkan materi yang telah disusun oleh Tim Pelaksana Pengabdian Kepada Masyarakat Universitas Jambi.

2. Metode tanya jawab, yaitu digunakan untuk merespons sejauh mana tingkat pemahaman peserta sosialisasi terhadap materi yang telah disampaikan oleh Tim Pelaksana Pengabdian Kepada Masyarakat Universitas Jambi.

3. Metode diskusi, yaitu pemateri dan peserta melakukan dialog untuk membahas masalah seputar pendirian Bank Sampah dan manajemennya.

\section{Hasil dan Pembahasan}

Bank Sampah merupakan media untuk memilah dan memanfaatkan sampah. Masalah sampah bukan hanya tanggung jawab pemerintah melainkan juga tanggung jawab masyarakat. Oleh karena itu, pemerintah telah mengeluarkan Peraturan Menteri Negara Lingkungan Hidup Republik Indonesia No. 13/2012 tentang Pedoman Pelaksanaan Reduce, Reuse dan Recycle melalui Bank Sampah.

Kegiatan pengabdian dilaksanakan dalam bentuk penyuluhan atau sosialisasi dan dilaksanakan pada Senin, 7 September 2020. Pelaksanaan kegiatan dilakukan di Balai Desa Simpang Sungai Duren dan diikuti oleh 20 orang peserta yang terdiri dari tua tengganai dan pengelola BumDes. Dalam kegiatan ini, tim pengabdian melibatkan 2 (dua) orang mahasiswa Program Studi S1 Akuntansi. 
Respons peserta sosialisasi dalam kegiatan pengabdian sangat bagus. Antusiasme peserta dapat dilihat dari tanggapan berupa pertanyaan terkait pendirian, pengelolaan, dan manfaat bank sampah. Desa Simpang Sungai Duren memiliki BumDes tetapi belum menjalankan kegiatan Bank Sampah. Sosialisasi ini diharapkan dapat menjadi inspirasi untuk pendirian bank sampah sehingga dapat mengurangi sampah, dan desa menjadi lebih bersih serta lingkungan menjadi sehat. Pemilihan dan menabung sampah rumah tangga yang dapat didaur ulang ke Bank Sampah akan memberikan nilai ekonomi sehingga diharapkan juga dapat meningkatkan perekonomian masyarakat setempat.

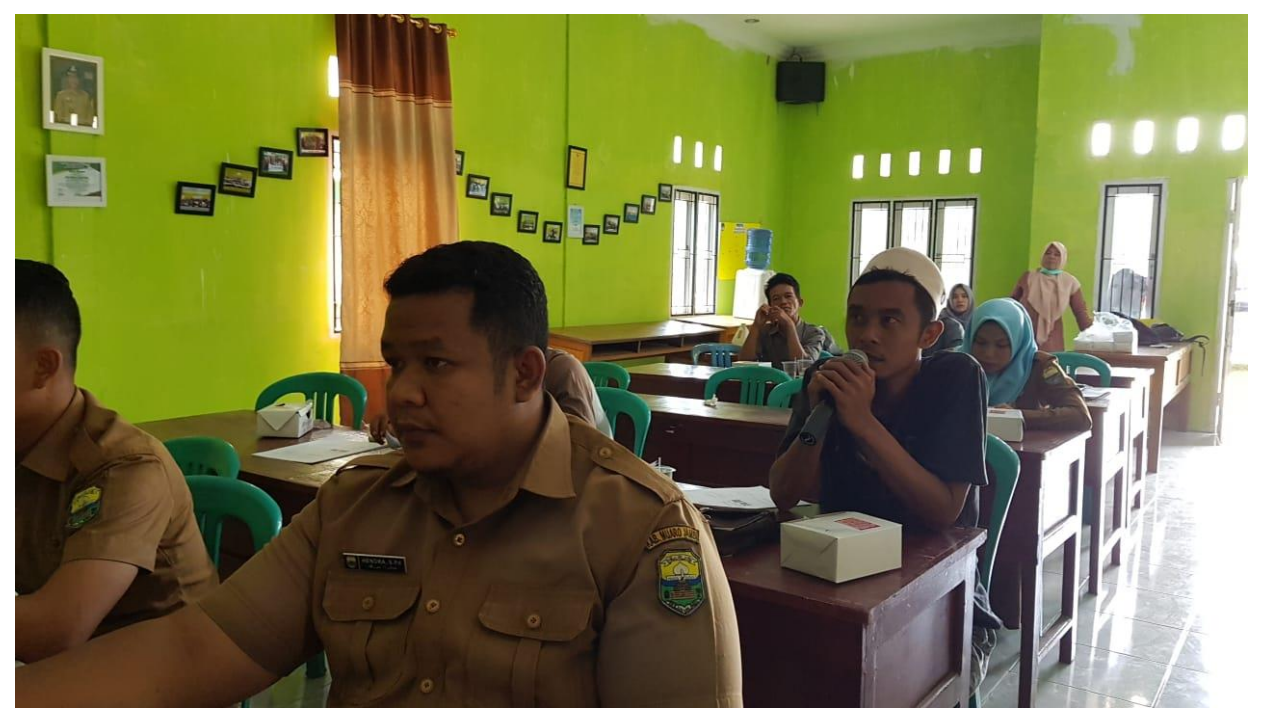

Gambar 1. Kegiatan Pengabdian kepada Masyarakat 2020

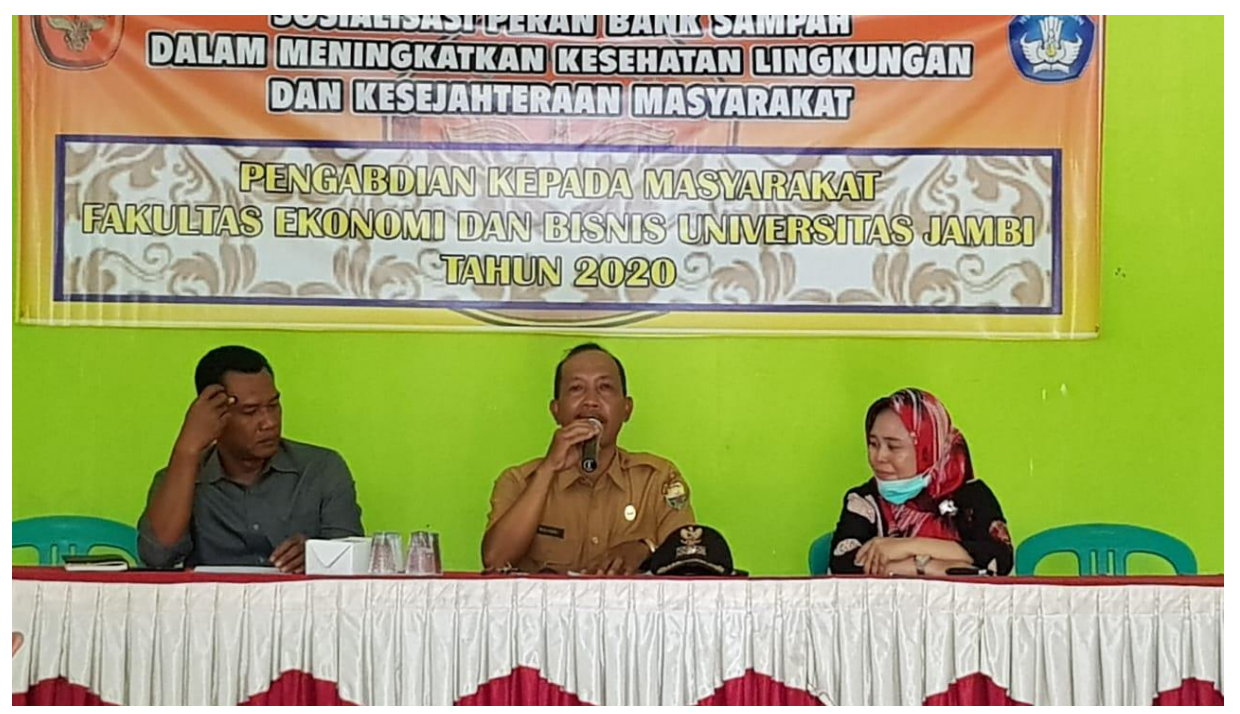

Gambar 2. Kegiatan Pengabdian kepada Masyarakat 2020 


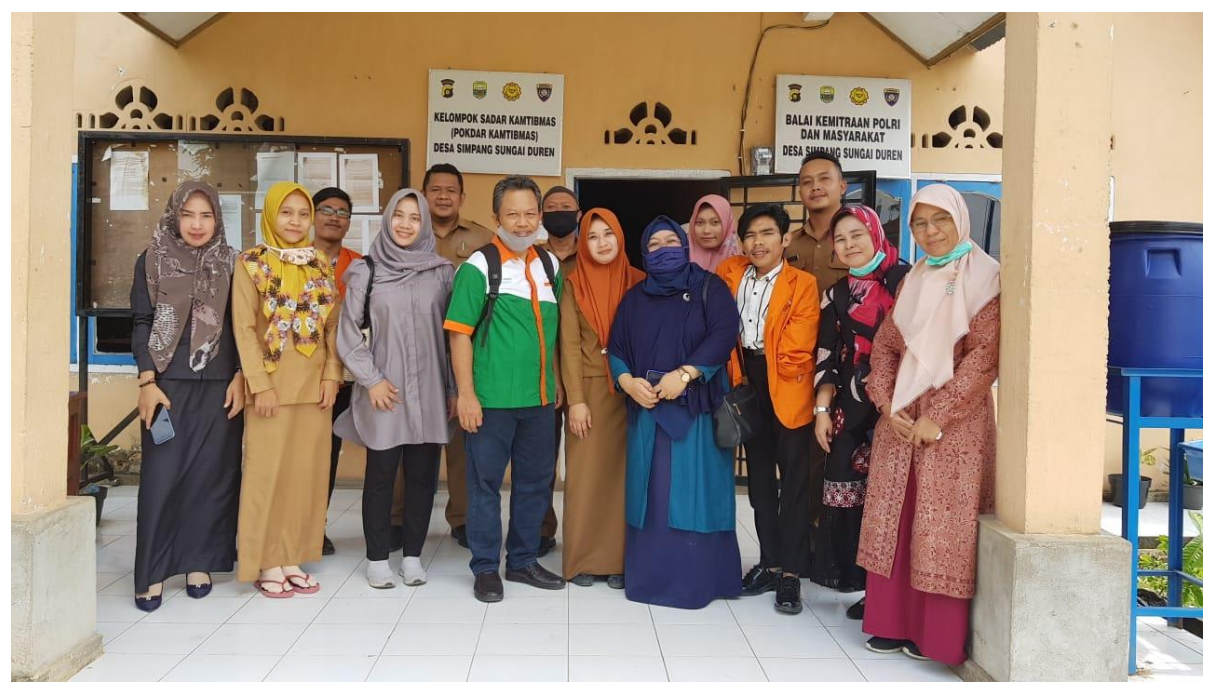

Gambar 3. Kegiatan Pengabdian kepada Masyarakat 2020

\section{Kesimpulan}

\section{Kesimpulan dan Saran}

Kegiatan ini telah dilaksanakan dengan lancar dan mendapatkan respons yang baik dari peserta kegiatan. Peserta merasa senang dan antusias karena dapat membuka wawasan mereka tentang manfaat dari mendirikan Bank Sampah. Bank sampah dapat menjadi media untuk menabung sampah sehingga mereka dapat menjaga lingkungan sekitar tetap bersih, dan kesehatan masyarakat pun menjadi lebih baik. Di samping itu, memanfaatkan limbah rumah tangga yang bisa didaur ulang menjadi sesuatu dengan nilai ekonomi dapat menambah pendapatan keluarga.

\section{Saran}

Hasil kegiatan ini berupa saran untuk Desa Simpang Sungai Duren mendirikan Bank Sampah sebagai salah satu solusi mengurangi limbah rumah tangga dan memanfaatkannya menjadi sesuatu yang bernilai guna serta dapat meningkatkan kesejahteraan masyarakat desa.

\section{Daftar Pustaka}

Kusumantoro, S. M. (2013). Menggerakkan Bank Sampah. Kreasi Wacana.

Peraturan Menteri Negara Lingkungan Hidup Republik Indonesia No. 13 Tahun 2012 tentang

Pedoman Pelaksanaan Reduce, Reuse dan Recycle melalui Bank Sampah. 